\title{
Withdrawing, Resisting, Maintaining and Adapting: Food Security and Vulnerability in Jumla, Nepal
}

\section{Kamal Gaire}

Department of Resource Management and Geography

Melbourne School of Land and Environment

The University of Melbourne

221 Bouverie Street, Carlton

Victoria 3053 Australia

Email: kgaire@student.unimelb.edu.au; kamalgaire@yahoo.com

Ruth Beilin

Department of Resource Management and Geography

Melbourne School of Land and Environment,

The University of Melbourne

221 Bouverie Street, Carlton

Victoria, 3053, Australia

T: +61390358273

Email: rbeilin@unimelb.edu.au

Fiona Miller

Department of Environment and Geography

E7A Building

Faculty of Science

Macquarie University

NSW 2109 Australia

T: +61298508425

Email: fiona.miller@mq.edu.au

\begin{abstract}
The food security discourse has shifted from a narrow focus on food supply to a greater consideration of access, entitlements and sustainability. An emphasis on vulnerability has coincided with increased recognition that the causes of food insecurity are the result of a complex interaction between ecological, social, political and economic events and processes. Understanding the strategies that people employ to respond to these risks is critical to identifying pathways for change towards greater food security. We explore people's explanations of and responses in the context of changes to their livelihoods and the wider social-ecological system in which they are embedded. An integrated vulnerability framework, drawing on a social-ecological systems approach, was applied to structure data collection, analysis and discussion in a food insecure region in Nepal. Using in-depth interviews, focus groups and historical data, we have examined negotiation processes, decision making, actions and interactions within social-ecological practices. Four distinct narratives and responses emerge-those of withdrawal, resistance, maintaining and/or adapting to food insecure situations. These stories reveal the complexity of managing the lived experience of food insecurity. They highlight the need for adaptive policy responses and point towards pathways that are likely to contribute to greater food security.
\end{abstract}

\section{KEYWORDS}

Food security; vulnerability; social-ecological systems; coping; adaptation; risk;

WORD COUNT (including references; but excluding tables and figures): 8254

Withdrawing, Resisting, Maintaining and Adapting: Food Security and Vulnerability in Jumla, Nepal

\section{FRAMING FOOD SECURITY}

Tremendous gains in the productivity and efficiency of food systems in recent decades have contributed to the world having more than enough food in aggregate to feed its population (Ericksen 2008; Millstone 2010). Despite this fact, undernourishment and chronic and acute hunger are still widespread in many parts of the 
world (FAO 2011, 2012). The latest IPCC report identifies food insecurity as the greatest risk facing humankind today (IPCC 2014). Consequently, halving hunger by 2015 has been an important part of the first Millennium Development Goal (Lal 2011), as agreed upon at the United Nations Millennium Summit in 2000 by some 192 countries. Although food security is firmly embedded within the global development agenda there are persistent and competing explanations of and approaches to food security at a number of scales. This paper draws out the potential in existing approaches, and highlights the possibilities for a more comprehensive understanding of interactions contributing to food insecurity at local levels. Ultimately it is our intention that this analysis will contribute to improving interventions, informed by and responding to the complexity inherent in all levels of engagement.

The concept of food security has evolved since it first emerged at the 1974 World Food Conference.

Historically, food security is understood as overall national, regional or even global, food supply compared with requirements. However, the increase in theoretical and empirical research using the concept of vulnerability has resulted in a shift from this conventional explanation to consideration of access and sustainability as core to this concept (Blaikie et al. 1994; Chambers 1989; Maxwell 1996; Sen 1981). The emphasis on vulnerability in food security studies coincided with the increased recognition that the causes of food insecurity are not only natural but also social, political and economic (Burg 2008). This more complex multi-dimensional understanding of vulnerability may assist in reframing the applicability and efficacy of the concept within assessments at all scales.

Vulnerability has been used differently within various theoretical traditions (McLaughlin and Dietz 2008) and especially in food security literature (Vogel et al. 2007). Key theoretical perspectives and approaches applied to the concept of food insecurity and vulnerability include: productivism, sustainable livelihoods (Chambers and Conway 1992), entitlements (Sen 1981) and political ecology (Blaikie and Brookfield 1987; Bohle et al. 1994; Watts and Bohle 1993). These approaches to the concept of vulnerability have contributed to an enriched understanding of complex issues associated with food security (Miller et al. 2010; Vogel et al. 2007). Vulnerability perspectives have placed emphasis on the role of wider political economic factors, such as the development ideologies underpinning global and national food regimes and in shaping food insecurity. Importantly this has led to documenting the highly differentiated nature of food insecurity by class, gender, age, ethnicity, caste and other social cleavages that shape people's (often highly unequal) access to food. In recent times, there have been attempts to utilize concepts from a social-ecological systems approach in describing vulnerability to food insecurity (for example see Ericksen 2008). Vulnerability analyses largely focus on actors within systems and associated 'processes of negotiation, decision making and action' whereas social-ecological systems (SES) approaches investigating resilience can potentially complement this by 'examining the interaction of social and ecological processes'(Miller et al. 2010). A social-ecological lens therefore, provides the opportunity to integrate these systemic considerations in the study of and response to food insecurity with an appreciation of the agency of actors and political economic structures. Yet, an outstanding challenge remains how to capture and explain these multiple interacting processes and structures.

In order to integrate these issues, our study begins with the lived experience of people within the context of a multi-scale SES. We consider coping, adaptation, and vulnerability as defined by farmers, residents, government officials and extension workers in the rural mountains of Jumla, Nepal. Their responses have effectively framed what it means to be resilient in the face of social and ecological shocks. These shocks necessarily trigger change in everyday practices. Understanding the coping and adaptation strategies that people employ to respond to risks and hazards is a critical part of providing a richer understanding of food insecurity (Barrett and Carter 2000;

Chambers and Conway 1992; de Waal 1991; Ericksen 2008; Lambert 1994; Maxwell 1996; Maxwell 2001; Sen 1981). One way of understanding coping and adaptation strategies has been to disaggregate problems and focus only on a single threat, such as drought or an increase in input costs, but this tends to produce a partial understanding of the situation (Quinn et al. 2011). As such, we consider multiple risks in the context of people's lived experiences of food security.

Risks of a social, political, economic and environmental nature interact to generate vulnerability and affect people's coping and adaptation options (Adger 2006; Ford 2009; Quinn et al. 2011; Reid and Vogel 2006). Depending upon whether risk emerges from sudden or gradual change, as manifest in seasonal changes, trends, or shocks (Chambers and Conway, 1992), people pursue different coping and adaptation strategies before, during and after the occurrence of risk. This time dimension of vulnerability is crucial in distinguishing the different strategies people do, and are able to, pursue as well as the interactions between them. Assessment of the sustainability of such actions needs to thus be understood in the context of the SES itself and also over the long term. 
Coping is generally understood to refer to short-term responses such as selling assets or reducing the number of meals to ensure survival in the near future. It involves active strategies to manage access to and use of resources to reduce vulnerability (Barrett and Carter 2000). Generally, coping strategies cannot be pursued over a period of time as they tend to erode well-being, relationships or the resource base upon which people depend. Adaptation means longer term changes in behaviour and livelihood strategies (over months or years) for the maintenance of food security in future (Berkes and Jolly 2001). Coping is commonly conceptualized in relation to managing current stresses or shocks and is often reactive, whereas adaptation is a more anticipatory and proactive concept associated with the potential to adapt to future uncertain changes by minimizing known vulnerability (Ericksen 2008). However, that distinction between coping and adaptation is not always clear.

There is a substantial literature documenting strategies for coping with stress and shocks. Chambers and Conway (1992) categorize coping into seven strategies: stint, deplete, move, hoard, claim, protect and diversify (Table 1). The strategies people pursue depend on their assets and relationships and their perception of the nature of the risk, such as whether it was unanticipated or understood to be a transitory risk. Blaikie et al. (1994, p. 53) refine this framing of coping by categorizing such strategies in light of their potential to undermine future ability to cope. The sale of productive assets such as land, farm tools (deplete) or eating less (stint) as a strategy, are regarded as actions that undermine a future ability to cope. In the case of disasters, Blaikie et al. (1994) categorise coping strategies into eight different categories (Table 1). This portrayal largely assumes people's ability to cope depends on their socio-economic and political conditions. As such insufficient attention is given to dynamic ecological considerations-a concern later taken up by Turner et al. (2003)and cultural mores.

However, Blaikie et al. (2004) emphasise that disasters are part of a continuum rather than a discrete event and vulnerability is shaped by longer-term environmental trends.

\section{Table 1:}

These classifications fail to appreciate both the time dimension and the social-ecological nature of risk and vulnerability. A more nuanced appreciation through an integrated analysis of different strategies people pursue is important to refining responses to food insecurity in ways that address its causes within the context of their SES.

This paper explores food security amidst the dynamic social-ecological changes in a remote mountainous landscape of Jumla, Nepal. This region experiences many of the challenges mountainous regions confront in terms of remoteness, ecological and climate change, and the transition from semi-subsistence to market oriented production (Beniston 2003; Shrestha and Aryal 2011). The Nepalese government regards it as one of the most food insecure parts of the country (NPC 2010a, 2010b). We specifically explore: i) the nature of key risks with respect to food insecurity, ii) how people cope with and adapt to food crises, and iii) how local communities' relationships with their SES influence their coping and response strategies. Following on from this introduction to the concept of food security, the paper provides an overview of the SES shaping food security in Jumla and a discussion of the methodology underpinning our research. We then outline the nature of risk in Jumla, before describing the four key narratives of coping and adapting to food insecurity we found there. We conclude by proposing a reframing of food security in ways that better take into account the lived experience of dynamic social-ecological changes and the differentiated nature of vulnerability. This reframing is likely to generate more appropriate and sustainable policy responses, sensitive to the particular social-ecological context in which people experience and negotiate risk. (1696)

\section{SOCIAL-ECOLOGICAL SYSTEMS OF JUMLA}

Jumla is located in a rugged high altitude mountainous landscape in the poorest region of mid-western Nepal. The remoteness of the region from the nation's capital and associated national services partly explains the low literacy rate of 32.2\% and its Human Development Index ranking as the 70th district out of 75 districts in the country (UNDP 2010). Remoteness and rugged terrain define this SES. It is vulnerable to extreme weather events (Shrestha and Aryal 2011) and until recently a need for self-sufficiency. Despite isolation, Jumli people have a history of trade and out-migration that has sustained their farming enterprises. As Shields (1991) notes, places on the margin manifest characteristics that speak both to their particular circumstances, but can be understood as shared by others in diverse locations. Indeed in the context of this case study, we argue that responses to coping and adaptation in Jumla reflect cycles common elsewhere in similarly remote and mountainous regions undergoing transition, and therefore, contributes to rethinking food security policy and practices beyond the borders of Nepal. 
Quality agricultural land is scarce in Jumla (DADO 2012). Besides being small in size (less than a hectare per person), farmland is highly fragmented (CBS 2013) and located on slopes with low moisture retention capacity with little or no irrigation facilities (MOAC 2010). Reliable rainfall and snowfall is critical for Jumla. Cereal crops dominate the predominantly subsistence family farms. Forests and pastureland constitute an important part of the Jumli farming system similar to other mountainous regions throughout the Himalayas. Historically Jumli people have been reliant on farming and other livelihood options such as livestock rearing, non-timber forest products (NTFPs), out-migration, trade, sourcing wild food, and selling their labour. With the recent construction of a road connecting Jumla, there is an increasing trend to integration of local, regional, national and international economies of food and agriculture.

Jumla society is stratified according to caste, livelihood, gender and place. Although officially outlawed, in practice Nepal still follows the Hindu caste system to a significant extent. The Jumli population of 108,734 (CBS 2011) is made up of three of the four primary castes: Kshatrias, Brahmins and Shudras or Dalits. Traditionally, caste and gender determined an individual's livelihoods, obligations, and expectations; and, caste and gender arguably contribute to shaping adaptation and coping strategies. This unique cultural feature mediates the experience of processes such as climate change, markets, national and regional political economy to influence the experience of food security in Jumla.

\section{METHODOLOGY: RESEARCHING DYNAMIC SOCIAL-ECOLOGICAL PROCESSES}

A vulnerability framework (Blaikie et al. 1994; Chambers 1989; Stephen and Downing 2001; Turner et al. 2003; Watts and Bohle 1993) integrating SES approaches (Berkes and Folke 2000; Gunderson and Holling 2002; Walker et al. 2002) was developed to structure data collection and analysis of food security in Jumla. Fieldwork was carried out in April, May and June of 2012 and 2013. We utilized a case study approach drawing on qualitative analysis of in-depth interviews and focus group discussions with local community members and other stakeholders. The qualitative case study approach offers an opportunity to explore a situation in sufficient detail and to unravel its complexity (Denscombe 1998) by describing the process and the outcomes. This is important in any study of food security due to the dynamic nature of risk and vulnerability. From 42 in-depth interviews, four focus group discussions (28 attendees), and meteorological and historical data, we analysed negotiation processes, decision-making, actions and interactions relevant to social-ecological processes and practices. Conversations were audio recorded, transcribed and analyzed via coding and thematic analysis. Respondents were purposively selected to capture the diversity of the community with gender, caste, main livelihood options, elevation, and remoteness. Local people's perceptions, practices, experiences, and their accounts of the processes are directly relevant to understanding complex phenomena such as vulnerability and food security (Byg and Salick 2009).

\section{SES RISKS IN JUMLA}

In their seminal discussion paper, Chambers and Conway (1992) classify the nature of risks that people are vulnerable to and identify them as being a trend, a seasonal change or a shock. They emphasize that people need to have a capability to avoid, withstand and/or recover from these risks for their livelihood to be sustainable (ibid). Usually risks of a social, political, economic and environmental nature interact together to generate vulnerability and affect the ability of individuals and households to employ coping and adaptation strategies (Adger 2006; Reid and Vogel 2006). Table 2 summarises the nature of the risks that people of Jumla identified. These are categorized as trends, seasonal change and shocks. Wider scale climatic changes and demographic changes, and food insecurity, are the most prominent risks.

Table 2:

The following sub-sections characterise major risks for Jumla respondents.

\subsection{Drought and erratic rainfall}

Research participants in Jumla perceive that rainfall behaviour has worsened in last 40 years. Jumla has undergone drought induced, famine-like situations in 1960, 1963, 1968, 1972, 1975 and in 1996. Almost all of the research participants perceive that over time Jumla is receiving less and experiencing more erratic rainfall, coupled with less snowfall. By erratic rainfall, they mean variable precipitation patterns and heavier downpours. Analysis of Jumla rainfall data (1977 to 2010) from the Government Department of Hydrology and Meteorology corroborates their perception as total rainfall and winter rainfall records indicate that the rainfall pattern is erratic and rain is gradually declining. 


\subsection{Rise in temperature}

Respondents also perceive a rise in temperature. Their evidence is that crops such as maize and pumpkins can now be grown successfully in high altitude areas such as Guthichaur, Dillichaur, Chhumchaur, and Patarasiareas where this was not possible in the past. Other cited indicators of rising temperature are drying spring water sources, increased disease and pest infestations in their crops, crops' early maturation, early flowering and budburst. Again, their perception is consistent with the empirical evidence (see Gentle and Maraseni 2012).

\subsection{Population growth}

Research participants noted unequivocally that there has been an increase in the population which was observed by an increase in the number of houses. This increase in housing corresponds with the decline in the size of family in Jumla as more young people are now living in a nuclear family than in the 1970s - a change from the predominantly extended family culture of Jumla. Analysis of population census data corroborates this situation. Some local development workers, however, questioned the reliability of such data. They, during interviews, argued that the census has partly failed to produce disaggregated data to reflect the number of people migrating out. Some respondents stated that people want to have their official address in Jumla even if they live most of the year elsewhere. This is mainly because Jumla is in the Government list of 'highly remote' districts providing some advantages in access to higher education and government jobs etc.

\subsection{Food shortage}

Jumla residents face three months of food scarcity. In April, May and June many households run out of their previous stocks and await the next harvest. This is largely the trend over the last 30 years. Many research participants reflected on this issue and independently suggested this pattern. Drought, hail storms, unexpected frost, lower agricultural productivity due to issues of temperature, number of light hours and declining soil fertility, lack of access to enough land resources - all interact with each other to cause food shortages.

\subsection{Seasonal change}

Apart from these risks there is a perception of, and some evidence, of seasonal change indicative of anthropogenic climate change. All the research participants believe that they are experiencing longer warm periods and shorter cold periods; and argue that crops are maturing earlier than before, resulting in a changed cropping calendar. The recent report of Intergovernmental Panel for Climate Change (IPCC) confirms this kind of seasonal change is evident in temperate zones globally (IPCC 2014). Participants report a trend to early onset of summer and an early budburst and flowering in apple and other temperate fruit trees, particularly in higher altitude areas. Flowering behaviour of such temperate fruits in lower parts of Jumla is different from season to season, as it is generally delayed and/or sporadic if the preceding winter was not cold enough.

From the above it is apparent that the risk landscape in Jumla is changing as a result of wider climatic changes as well as more local social changes. The interaction between these multi-scale changes and people's varying experiences of food insecurity follows.

\section{FOUR VARIATIONS IN RESPONSE TO FOOD INSECURITY}

Historically, Jumli people combine different livelihood pursuits—agriculture, animal husbandry, home industry, exploitation of wild products, trade, and out-migration for work (Bishop 1990: 157) — to devise coping and adaptation strategies that suit their particular conditions. People's strategies distinguish between what is a trend, a seasonal change or a shock and are combined and employed differently by respondents even though they may be responding to the same trend, seasonal change and/or shock depending on opportunity and individual circumstances. People's response strategies are mainly undertaken as individual pursuits although collective initiatives are also apparent. While people of Jumla provide historical evidence of responding to multiple risks associated with food insecurity, their response strategies are not static, reflecting changes in their local socialecological systems and the success or otherwise of particular strategies. In effect these strategies underpin their social-ecological resilience. Figure 1 revisits the earlier work of Chambers and Conway and Blaikie et al. (Table 1) but importantly, reframes it within the context of a changing social-ecological system.

Four narratives emerge from the diverse risks and social-ecological conditions that expose the complexity of coping and adaptation to food insecurity, each with different implications for individual and collective long-term well-being and sustainability. People are, not necessarily in sequential order, withdrawing, resisting, maintaining, and/or adapting to food insecure situations. These stories show the complexity of the lived experience of managing food insecure situations and highlight the importance of both individual and household level responses, as well as collective actions in the overall Jumla response to food insecurity. It is through understanding the diverse narratives of 'coping with' and 'adaptation to' food insecurity that opportunities 
which resonate more strongly within local social-ecological relations can emerge. This discussion also reveals the local manifestation and negotiation of global, regional and national trends, notably in terms of climate change and market integration.

Figure 1:

\subsection{Withdrawing}

People withdraw when all their positive options to manage their food security are exhausted and they are compelled to employ strategies that undermine their ability to cope with similar situations in the future. Examples of withdrawing strategies are those where Jumla respondents have had to spend their life savings, sell productive assets, start consumption rationing, eat seeds intended for subsequent plantings, skip medicines, take their children out of school and send children away to work elsewhere. Finally the 'choice' to migrate out of the district can be considered as the ultimate 'withdrawal' from the Jumla social domain. These responses do not necessarily follow a sequence - e.g., eat seeds last. Rather the apparent 'options' are weighed up according to the current context at the time of the crisis or are a catalyst for evaluating their situation and are dependent on the relationships and resources of each household. Relatively well-off participants employ strategies only during extreme events such as serious illness in the family. Even in normal seasons, many dalits and other land poor participants reported that they needed to either sell their productive animals or get loans to be able to afford festival celebrations.

The Jumla case confirms the findings of studies undertaken elsewhere (see Chambers and Conway 1992; Ford and Beaumier 2011; Grobler 2014; Osbahr et al. 2008) that consumption rationing is one measure that people in a food crisis adopt routinely. As mentioned earlier, people may be aware of but unable to avoid the long-term negative consequences of particular strategies. Coping strategies during food crises are known to be preoccupied with avoiding depletion of assets rather than maintaining consumption levels (de Waal 1991). Participants in Jumla reported that eating less, eating inferior food, even not eating for days were some of the strategies they use during a food crisis. As one participant said:

"...what we used to do is collect some edible plant leaves from the forest (bethe, sisno), add some cereal flour and boil them to make slurry and drink for dinner or lunch"

When it seems that stinting does not work, people start depleting their assets. Spending savings, selling goats, chickens and/or sheep and even selling cows, bullocks and/or buffaloes is the next step of coping with a food crisis. They know these responses make them more vulnerable to any future hazards. Some participants even had to sell some of their productive land to manage severe food crises resulting from drought or serious health problems.

Another common way of withdrawing in Jumla is to migrate out - both for short and long term. Migration has been a part of Jumli people's life style for generations. While all of the interview participants, across all castes, mentioned that at least one member of their family had migrated for work in the past, the land poor tend to employ this strategy the most. Participants mentioned two equally important benefits of this kind of response: i) it saves food which can be used for a longer time by remaining family members, and ii) remittances can be used to buy food and other necessary items. Short term migration normally starts in July when the planting of the summer crop is complete and migrants return after winter. Withdrawing for migration is essentially an end point but here it can be understood to lead to an improved food security situation. Overall, 'withdrawing' strategies exhibit the least power/agency (because people are frequently locked-in); so in term of resilience, this is the most vulnerable time to risks and does not contribute to longer-term resilient social-ecological systems.

\subsection{Resisting}

Whereas 'withdrawing' results in an erosion of long-term capacity to cope with change, 'resisting' demonstrates a greater degree of agency and potentially access to a more diverse suite of relations and resources. Yet these strategies do not consider longer term social-ecological implications. In their struggle to respond to a changing risk landscape people pursue several resistance strategies in Jumla: i) increasing farm area, ii) planting new crops and new varieties, and iii) changing expectations of activities associated with the cropping calendar - each of these reflect responsiveness to changing social-ecological relations.

With population pressure resulting in increased demand for food, households seek to increase their land beyond what they inherit, predominantly through forest clearance. As one participant said: 
“...farm land that my grandfather used to own and cultivate was enough to feed his family at that time. But now that land is just not enough... we have become 17 people from my two grandparents and the inherited land I now have is not enough for my family.... I had to increase my farm land... I started cultivating the adjoining forest land. In 1997, the Government kindly legalized it by registering it in the book of land registration"

This story is shared by many in Jumla where the total cultivated area has increased almost eight times in the last 40 years. Bishop (1990) recorded a total of 2990 ha of land under cultivation in 1969/70. Official total cultivated land in 2011 is 26896 ha (DADO 2012). Similarly, an increase in the irrigated land (jyulo or khet) is significant. In 1868, Jumla had only 584.1 ha of khet land (Bishop 1990). In 1968 it reached 846.5 ha (ibid) and in 2011 it was 3173 ha (DADO 2012). Per capita land holding has increased from 0.06 ha to 0.2 ha over the last 40 years.

Clearing forests for farming has been an important coping strategy in Jumla. But who gets to pursue this strategy is largely determined by the prevalent caste system. Despite a three-fold increase in the average land ownership Dalits in Jumla generally have less landholding than their upper caste neighbours. Dalit participants identified three main reasons as to why they have less land. Dalits had to do forest clearing for upper caste people so they had less time for their own clearing works. Second, they received less fertile, marginal land to clear-left by others - eventually abandoning it after one or two cropping seasons due to insufficient yields. Thirdly, after clearing and cultivating on the forestland at the time of official registration, elites fraudulently got the dalit land registered in their name, legally depriving the dalits of land ownership. Upper caste participants refuted these claims and blamed dalits for being 'lazy' in the past and not willing to face the risk associated with farming in the forestland, such as wild animals destroying their crops. These explanations reveal how social-ecological relations are shaped by cultural prejudices and structural inequalities.

Resisting does not stop at increasing farmland. Most people are constantly making use of opportunities to try new crops and their varieties. Selection is influenced by a combination of characteristics and preferences: i) climatic suitability of new crops, ii) availability of high yielding crops and varieties, iii) ease of crop to grow, iv) crops and varieties that have higher market demand, v) consumption preferences work against growing crops that are socially regarded as inferior food, and vi) people are compelled to grow certain crops because some climatic shocks, such as delayed monsoon, prevent them from growing their intended crops. Research participants were asked if they have changed their cropping calendar in the last 15 years and if so to describe such changes. Farmers are delaying sowing time except for paddy and despite this they are harvesting earlier. Yet there is a variation between high and low altitude areas, with the change in harvesting time of major crops in high altitude areas small or similar to historic expectations.

Farmers are increasingly establishing commercial apple orchards, initiating semi-commercial vegetable farming and vegetable seed production schemes. Interview participants, however, noted that despite having a good chance of making money out of these three kinds of commercialization, not all could start this business. Variously, they listed declining family size, land holding size, transportation difficulties, and health of family members, as important determining factors for households to start such farming. For example households with a nuclear family cannot spare labour as required for commercial vegetable farming. Similarly, land poor households cannot afford to establish an apple orchard that competes with staple food crops on little available land. It also requires substantial financial investment for the initial six years before there are apples, so investment is without any return for some time. This reinforces earlier findings that how people get affected and respond to risks depends not only on the severity of such risks but also on their own social, economic, ecological and cultural conditions (Adger and Kelly 1999; Barua et al. 2013; Mendelsohn et al. 2006).

Historically August/September used to be very cold in high altitude areas; cold enough that seeds sown then remained dormant germinating at the end of winter. Nowadays, if seeds are sown in August/September they start germinating within a month and seedlings get burnt during the following cold winter. So planting has been rescheduled, except for paddy for cultural reasons, to the start of the winter-October/November. Therefore historical continuity assists in trying new livelihood strategies; however, the resisting strategies reflect considerable changes in prevailing social-ecological conditions, requiring major adjustments.

\subsection{Maintaining}

Maintaining is another response strategy where people make claims on friends, families, extended families, neighbours, NGOs and government in Jumla. Hoarding food stock and preempting imminent future risks such 
as seasonal hungry months, or roadblocks, is another strategy increasingly deployed. By engaging in these kinds of strategies people aim to 'maintain' the status quo in terms of food security.

With the increased proximity to market and the increasing influence of a cash-based economy, facilitated by improving transport links and migration, the way people make claims on food items has changed in recent times. Popular practices in the past included borrowing food grains, but this is rapidly declining in Jumla. Instead, people prefer to get a cash loan or purchase food on credit. Participants said that the traditional practice of lending grains as a loan from grain merchants, a practice that required borrowers to return the grains back with interest the next season, does not exist anymore. Few remaining landlords in Jumla sell their grains for cash. Even farm labourers preferred taking cash for their wages rather than the traditional system of grains. With food available in the market in recent years, people believe that having cash in hand gives people the power to choose food of their preference.

Similarly, one of the popular coping strategies of the past—working as lagitya-is almost extinct. In Jumla, lagi-lagityas is the system of 'long term hereditary contractual labour relations' (Gurung 2003, p. 13) where low caste land poor dalits work as lagitya for their higher caste landlords, lagies, to supplement their own agricultural produce. Traditional rituals and Hindu culture prevented higher caste groups ploughing agricultural land. They had to rely on low caste people for ploughing. Land poor lagityas used to get a certain amount of grain, depending on the quality of land they ploughed, for their service. Many regard this system as feudal and discriminatory and they do not want to practice it.

Participants said that share-cropping is becoming a popular coping strategy in Jumla. Land-poor farmers cultivate either their landlord neighbours' land or the land belonging to the neighbours who have family circumstances restricting them from doing their own cultivation.

Food aid from the Government and NGOs is another option for making a claim on food in Jumla. The government's food aid program started in 1972 when Jumla faced a drought induced famine-like situation. Since then, Jumla receives food aid every year in different forms, including: government provision of grain at a subsidized rate; the World Food Program (WFP) providing food/cash for work programs in selected villages; and some bilateral donors such as from the USA, Japan, and European Union (EU) are also involved in delivering food aid there.

During the farming season, people work extra hours in the fear that they may not get work in coming seasons. They save money to be used in the months when there is less work available such as winter. Apart from that, people stockpile food materials as roads supplying food materials may get blocked and supply obstructed due to excessive snow during winter or rainfall. There is also the reality of this weather triggering landslides along the roads, during the rainy season. Low-income earners cannot afford to stockpile grain because it reduces their immediate income and their physical assets may not be sufficient to safely store grains. Some participants recall resorting to selling their assets or borrowing loans to be able to stockpile grains before the start of the rainy season. In resilience terms, these strategies are about maintaining the status quo and keeping within system boundaries so little thought is given to the future and/or multiple risks.

\subsection{Adapting}

Individual diversification of sources of food and income, and collective community efforts are major strategies people in Jumla have engaged in to move beyond coping to adapt to social-ecological uncertainties threatening their food security. Entitlement relations are also changing as a result of the increased integration of Jumla into the market economy.

Sen (1981, p. 2) writes that people get food through five different types of 'entitlement relationships' in privateownership market economies. These are production-based entitlement (growing food), trade-based entitlement (buying food), labour entitlement (working for food), inheritance and transfer entitlement (food being given by others) and intra-family allocation food as extended entitlements (ibid). While almost all participants noted that the number of sources of food and income have increased in recent times (in amount and diversity), the contribution of these entitlements to their livelihoods has changed. For example people believe that the contribution of production-based entitlement is declining whereas trade-based, labour and transfer entitlements have increased in recent years. With the construction of new roads, portering as a source of supplemental income is declining. Similarly, the availability of cheap Chinese garments is jeopardizing traditional sewing. Livestock numbers and associated income are declining as households cannot keep large herds owing to 
declining family size, deforestation and the community forestry programs banning livestock entry in the forest areas.

The main food sources and the way people obtain access to these food sources in Jumla have also changed. We asked research participants their three most important sources of food and any changes in these sources in the last 15 years, identifying rice, barley and maize. Rice and maize have largely replaced millet, buckwheat and other traditional food sources such as chino and kaguno resulting in a visible change in food habits. People in Jumla overwhelmingly regard rice as 'elite' food. It is easier and quicker to cook in comparison to making roti (chapatti) out of barley, millet, buckwheat and/or wheat flour - the more popular food items in the past. Women participants have welcomed this change as it reduces some of the drudgery in their workload. The milling process for maize, millet, wheat and barley in traditional water powered mills is labour intensive and is considered to be a women's job. Buying milled rice means less milling work to make maize/millet/wheat/barley flour as they will need less flour. It generally needs four kilos of maize or barley or wheat to buy one kilo of rice. Given Jumla's agro-climatic conditions, paddy can only be grown on limited land; not enough to meet their requirement. As such people mostly rely on food aid and market access for rice.

Wild foods have been precious sources of food to fall back on when crops failed. Participants recalled when they relied on fruits, vegetables and root crops found in the wild. Most respondents believe that the contribution of these sources to their everyday food items is declining. In the past everyone collected these products, but now it is only the land-poor respondents living in the remote parts of Jumla that still source considerable food from the wild.

While non-timber forest products (NTFPs) continue to be number one income source for many households, participants however reported a marked decline in the availability of most of these species specially ones that fetch higher market prices such as yarchagunma (Cordyceps sinensis), guchhichyau (Morchella conica) and wild garlic (Fritillaria cirrhosa). Participants attribute the dramatic rise in price of these three NTFPs (for example NRs 2 ten years ago to NRs 5 five years ago and in 2012 NRs 400 per piece of sun dried yarchagumba) to excessive demand from China. The time it takes to collect the same amount has almost doubled in recent years. They blame deforestation, over harvesting, illegal harvesting and the rise in temperature for such decline. This indicates the importance of considering food security from a SES perspective rather than farming systems perspective alone.

Participants mentioned that they have been involved in four key collective community actions in their bid to adapt to changing circumstances. Jumli communities have organized themselves in different types of community groups such as community forestry users' groups, farmers groups, mothers' groups, and women's groups. The formation of these groups was largely initiated by external agencies like Government Departments or NGOs, but participants believe that they needed such community groups. In the absence of external support, community groups are often the only avenue for local people to get help (Gaire 2011). Some groups make cash and grains available on credit for needy members, using their saving and credit schemes. Members also share new farming technologies with each other. Official statistics at district level show a steady increase in the number of such community groups (DADO 2012).

Collectively, Jumla is constructing small irrigation canals, to tap small sources of available water. There is shrinking water availability due to erratic and uncertain rainfall, and participants mentioned they have collectively either made new irrigation facilities or repaired old ones. Similarly, communities are engaging in the construction of local roads and small bridges over seasonal creeks so that movement of people and supplies is not restricted during rainy seasons. With little external support, many communities have been able to bring piped water into their homes. The community seed bank is another collective action, for at least two different village communities. These 'adaptation' strategies tend to anticipate potential risks that the social-ecological systems may face in future. These strategies are more likely to contribute to resilient outcomes because of their focus on diverse, innovative, and adaptive solutions but these too are subject to wider structural impediments.

\section{DISCUSSION AND CONCLUSIONS}

As demonstrated here, Jumla has been experiencing incremental and significant changes in its social-ecological systems due to local, regional and wider scale changes. Understood within Nepal to be a food insecure place, the case study demonstrates that food insecurity is seasonal, demographically uneven and reflects both historical and cultural realities of caste and land tenure, as well as biophysical change. There is a continuous ecological transition in Jumla: less forest, less wild harvesting, more farming, changed timing and availability of precipitation, warmer temperatures; and, the social realities that both respond to and are the impetus for physical 
change. The persistence of caste and class relations, changing population dynamics, out-migration and increasing integration of the Jumla into the national economy are also resulting in changing livelihood strategies.

Extending Blaikie et al. (1994) and Chambers and Conway's (1992) early categorisations, we examined food insecurity as an outcome of interlinked, multiple risks manifesting in combination or separately within Jumla's social-ecological setting. This extends the literature on vulnerability and food security by demonstrating the complex series of responses and interactions within communities to social and ecological shocks. In distinguishing between the variations in response to food insecurity we have argued that there are four strategies that locals distinguish as coping mechanisms. 'Withdrawing' reflects an almost total inability to consider the future, resulting in the selling of assets, disposal of seeds and out-migration. This depletion of resources is likely to accelerate vulnerability. 'Resistance' is a more subtle response, depending on socio-economic conditions and emphasising the agency of individuals and households. People try novel approaches, extend land and modify their cropping, committing to change and seeing innovation (the constant trying and experimenting with new ways while responding to risks) as a way forward. 'Maintaining' the current activities and daily interactions results in attempts to keep the status quo but to do so requires engaging in premeditated (as in hoarding) and spontaneous opportunism (as in food aid). Withdrawing, resistance and maintaining strategies are all short-term ways of coping. 'Adaptation' is the only long-term response identified in our study as it is focused on planning for change through diversification of livelihoods and anticipation of benefits in the future.

Using these narratives of withdrawing, resisting, maintaining and/or adapting we demonstrate the food insecurity in Jumla is not a problem of too little production alone. If there is not enough rice, for example, then food aid provides rice. However, people in Jumla produce other grains. In this case, policy mistakenly associates food insecurity with food preferences.

Local people have always attempted to integrate their responses to adversity through re-organising what is available to them at the time of the crisis but with an eye to the consequences of their actions within their socialecological system. Their strategies for coping and adaptation are buffers against food insecurity and vulnerability to risks within the SES across the seasons and over time.

Globally, the case of Jumla speaks to the level of socially differentiated and integrated support and services that governments and aid need to consider in response to topical (and traumatic) issues. The four response strategies described in this paper, taken together, present an opportunity to mediate more complex policy and practice outcomes. Noting that focus in many developing countries, as in Nepal, is often on improving agriculture as 'the sole solution' to food insecurity, we argue for policies and resources that support negotiated, differentiated and diverse coping and adaptation strategies. Specifically, Jumla requires differentiated extension support for small farmers. This could encourage diversity in farms, support improving livelihood options off the farm and at a national level - the implementation of a land reform program for fair and just access to land resources. Further institutional changes in this vein could ensure certainty of access to resources. These would contribute to a more sustainable use of ecological resources. Government policy could integrate divergent programs to make explicit possible interconnections among food security, climate change, agriculture, biodiversity, gender, health and education outcomes. The importance of moving beyond a simple interpretation of food insecurity is that real food security reflects a whole of system, integrated landscape approach.

\section{ACKNOWLEDGEMENT}

The authors thank the people of Jumla who participated in this research for generously providing their time and sharing their views, practices and experiences. Thanks are also due to participants from Government and NGOs both within and outside Jumla for their time and knowledge. We would also like to thank AusAID and The University of Melbourne for funding field work.

\section{REFERENCES CITED}

Adger WN (2006) Vulnerability. Glob Environ Chang 16(3):268-281. doi:10.1016/j.gloenvcha.2006.02.006

Adger WN, Kelly PM (1999) Social vulnerability to climate change and the architecture of entitlements. Mitig adapt strategies glob chang 4:253-266. doi:10.1023/a:1009601904210 
Barrett CR, Carter MR (2000) Can't get ahead for falling behind: New directions for development policy to escape poverty and relief traps. Choices. http://farmdoc.illinois.edu/policy/choices/20024/2002-4-06.pdf. Accessed 25 September 2012

Barua A, Katyaini S, Mili B, Gooch P (2013) Climate change and poverty: Building resilience of rural mountain communities in South Sikkim, Eastern Himalaya, India. Reg Environ Change 14(1):267-280. doi:10.1007/s10113-013-0471-1

Beniston M (2003) Climatic change in mountain regions: A review of possible impacts. In: Diaz H (ed) Climate Variability and Change in High Elevation Regions: Past, Present \& Future. Springer Netherlands, pp 5-31.

Berkes F, Folke C (2000) Linking social and ecological systems for resilience and sustainability. In: Berkes F, Folke C, Colding J (eds) Linking Social and Ecological Systems: Management Practices and Social Mechanisms for Building Resilience. Cambridge University Press, Cambridge, UK, pp 1-25

Berkes F, Jolly D (2001) Adapting to climate change: social-ecological resilience in a Canadian western Arctic community. Conservation Ecology 5(2):18. http://www.consecol.org/vol5/iss2/art18. Accessed 7 June 2013

Bishop BC (1990) Karnali under stress: Livelihood strategies and seasonal rhythms in a changing Nepal Himalaya. The Committee on Geographical Studies, The University of Chicago, Chicago.

Blaikie P, Brookfield H (1987) Land degradation and society. Methuen, New York.

Blaikie P, Cannon T, Davis I, Wisner B (1994) At Risk: Natural hazzards, people's vulnerability and disasters. Routledge, London and New York.

Bohle HG, Downing TE, Watts MJ (1994) Climate change and social vulnerability: Toward a sociology and geography of food insecurity. Glob Environ Chang 4(1):37-48. doi:10.1016/0959-3780(94)90020-5

Burg, J (2008) Measuring populations' vulnerability for famine and food security interventions: The case of Ethiopa's Chronic Vulnerability Index. Disasters 32(4):609-630. doi:10.1111/j.0361-3666.2008.01057.x

Byg A, Salick J (2009) Local perspectives on a global phenomenon - climate change in Eastern Tibetan villages. Glob Environ Chang 19(2):156-166. doi:10.1016/j.gloenvcha.2009.01.010

CBS (2011) Preliminary results of national population census 2011. Central Bureau of Statistics, National Planning Commission, Kathmandu, Nepal.

CBS (2013) National sample census of agriculture 2011/12. Central Bureau of Statistics, National Planning Commission, Kathmandu, Nepal.

Chambers R (1989) Vulnerability: How the poor cope (Editorial Introduction), IDS Bulletin 20(2):1-7.

Chambers R,Conway G (1992) Sustainable rural livelihoods: Practical concepts for 21st century. Institute of Development Studies, University of Sussex, Brighton, UK.

DADO (2012) District Agriculture Development Programs and Statistics. District Agriculture Development Office, Jumla, Nepal.

de Waal A (1991) Emergency food security in Western Sudan: What is it for? In: Maxwell S (ed) To Cure all Hunger: Food Policy and Food Security in Sudan. Intermidiate Technology, London, pp 66-84

Denscombe M (1998) The Good Research Guide for Small-scale Social Research Projects. Open University Press, Buckingham, UK.

Ericksen PJ (2008) What is the vulnerability of a food system to global environmental change? Ecol Soc 13(2):14. http://www.ecologyandsociety.org/vol13/iss2/art14/. Accessed 15 March 2011

FAO (2011) The state of food and agriculture 2010-11. Food and Agriculture Organization of the United nations, Rome. 
FAO (2012) The state of food and agriculture 2011-12. Food and Agriculture Organization of the United Nations, Rome.

Ford J (2009) Vulnerability of Inuit food systems to food insecurity as a consequence of climate change: A case study from Igloolik, Nunavut. Reg Environ Change 9(2):83-100. doi:10.1007/s10113-008-0060-x

Ford JD, Beaumier M (2011) Feeding the family during times of stress: Experience and determinants of food insecurity in an Inuit community. Geogr J 177(1):44-61. doi:10.1111/j.1475-4959.2010.00374.X

Gaire K (2011) Grassroots women's groups in Nepal: Understanding their sustainability. Lambert Academic Publishing, Saarbrucken, Germany.

Gentle P, Maraseni TN (2012) Climate change, poverty and livelihoods: Adaptation practices by rural mountain communities in Nepal. Environ Sci Policy 21:24-34. doi:10.1016/j.envsci.2012.03.007

Grobler WC (2014) Food insecure household coping strategies: The case of a low income neighborhood in South Africa. Mediterranean Journal of Social Sciences 5(13):100-106. doi:10.5901/mjss.2014.v5n13p100

Gunderson L, Holling CS (2002) Panarchy: Understanding transformations in human and natural systems. Island Press, Washington D.C., USA.

Gurung O (2003) Notes on Lagi-Lagitya relations in Jumla. Occasional Papers in Sociology and Anthropology $8: 12-17$.

IPCC (2014) Summary for policymakers. In Field CB, Barros VR, Dokken DJ, Mach KJ et al (eds) Climate Change 2014: Impacts, Adaptation and Vulnerability. Part A: Global and Sectoral Aspects. Contribution of Working Group II to the Fifth Assessment Report of the Intergovernmental Panel on Climate Change. Cambridge University Press, Cambridge, UK and New York, USA, pp 1-32

Lal M (2011) Implications of climate change in sustained agricultural productivity in South Asia. Reg Environ Change 11(1):79-94. doi:10.1007/s10113-010-0166-9

Lambert RJ (1994) Monitoring food security and coping strategies: lessons from information collection and analysis in Mopti, Mali. Disasters 18(4):322-43. doi:10.1111/j.1467-7717.1994.tb00320.x

Maxwell S (1996) Food security: A post-modern perspectives. Food Policy 21(2):155-70.

Maxwell S (2001) The evolution of thinking about food security. In Devereaux S, Maxwell S (eds) Food security in Sub-Saharan Africa. ITGD Publishing, London, UK, pp 13-31

McLaughlin P, Dietz T (2008) Structure, agency and environment: Toward an integrated perspective on vulnerability. Glob Environ Chang 18:99-111. doi:10.1016/j.gloenvcha.2007.05.003

Mendelsohn R, Dinar A, Williams L (2006) The distributional impact of climate change on rich and poor countries. Environment and Development Economics 11(2):159-78. doi:doi:10.1017/S1355770X05002755

Miller F, Osbahr H, Boyd E, Thomalla F, Bharwani S, Ziervogel G, Walker B, Birkmann J, van der Leeuw S, Rockstrom J, Hinkel J, Downing T, Folke C, Nelson D (2010) Resilience and vulnerability: Complementary or conflicting concepts? Ecol Soc 15(3):11. http://www.ecologyandsociety.org/vol15/iss3/art11/. Accessed 9 May 2011

Millstone E (2010) Chronic hunger: A problem of scarcity or inequity? In L Mehta (ed) The Limists to Scarcity. Earthscan Ltd, Dunstan House, 14a St Cross Street, London, pp 179-194

ABPSD (2010) Statistical Information on Nepalese Agriculture. Agri-business Promotion and Statistics Division (ABPSD), Ministry of Agriculture and Cooperatives, Government of Nepal, Kathmandu.

NPC (2010a) The Food Security Atlas of Nepal. National Planning Commission (NPC), Government of Nepal, Kathmandu. 
NPC (2010b) Millennium Development Goal Needs Assessment. National Planning Comission (NPC), Government of Nepal, Kathmandu.

Osbahr H, Twyman C, Adger NW, Thomas, DSG (2008) Effective livelihood adaptation to climate change disturbance: Scale dimensions of practice in Mozambique. Geoforum 39(6):1951-1964. doi:10.1016/j.geoforum.2008.07.010

Quinn C, Ziervogel G, Taylor A, Takama T, Thomalla F (2011) Coping with multiple stresses in rural South Africa. Ecol Soc 16(3):1-20. doi:10.5751/ES-04216-160302

Reid P, Vogel C (2006) Living and responding to multiple stressors in South Africa—glimpses from KwaZuluNatal. Glob Environ Chang 16(2):195-206. doi:10.1016/j.gloenvcha.2006.01.003

Sen A (1981) Poverty and Famines: An Essey on Entitlement and Deprivation. Clarendon Press, Oxford.

Shields R (1991) Places on the Margin: Alternative Geographies of Modernity. Routledge, London.

Shrestha A, Aryal R (2011) Climate change in Nepal and its impact on Himalayan glaciers. Reg Environ Change 11(1):65-77. doi:10.1007/s10113-010-0174-9

Stephen L, Downing TE (2001) Getting the scale right: A comparision of analytical methods for vulnerability assessment and household-level targeting. Disasters 25(2):113-135. doi:10.1111/1467-7717.00165

Turner BL, Kasperson I, Matson RE et al (2003) A framework for vulnerability analysis in sustainability science. Proceedings of the National Academy of Sciences of the United States of America 100(14):8074-8079. doi:10.1073_pnas.1231335100

Vogel C, Moser S, Kasperson R, Dabelko G (2007) Linking vulnerability, adaptation, and resilience science to practice: Pathways, players, and partnerships. Glob Environ Chang 17(3-4):349-364. doi:10.1016/j.gloenvcha.2007.05.002

Walker B, Carpenter SR, Anderies J, Abel N et al (2002) Resilience management in social-ecological systems: a working hypothesis for a participatory approach. Conservation Ecology 6(1):14. http://www.consecol.org/vol6/iss1/art14. Accessed 25 October 2012

Watts MJ, Bohle HG (1993) The space of vulnerability: the causal structure of hunger and famine. Prog Hum Geogr 17(1):43-67. doi: 10.1177/030913259301700103

Fig 1: Framework for understanding coping and adapting to food insecurity within Jumla social-ecological systems 


\section{Withdrawal}

'withdrawing' reflects an inability to consider the future such as spending savings; selling productive assets

\section{Resistance}

'resistance' involves subtle responses, depending on socioeconomic conditions and emphasising agency by households and individuals such as increasing farm land; planting new crops

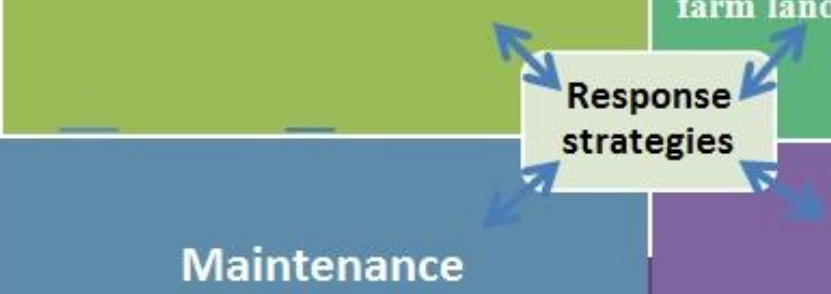

'maintaining' involves keeping the status quo by engaging in premeditated and spontaneous opportunism such as claiming; hoarding

\section{Adaptation}

'adaptation' is the long-term response; focuses on planning for change with anticipation of benefits in future such as diversification of food and income sources; collective actions

\section{Withdrawal}

'withdrawing' reflects an inability to consider the future such as spending savings; selling productive assets

\section{Resistance}

'resistance' involves subtle responses, depending on socioeconomic conditions and emphasising agency by households and individuals such as increasing farm land; planting new crops

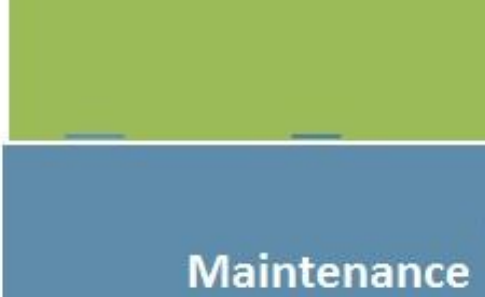

'maintaining' involves keeping the status quo by engaging in premeditated and spontaneous opportunism such as claiming; hoarding

\section{Adaptation}

'adaptation' is the long-term response; focuses on planning for change with anticipation of benefits in future such as diversification of food and income sources; collective actions 
Table 1: Classifying coping strategies (strategies that undermine the future ability to cope are grouped as 'sustainable' and visa-versa)

Blaikie et al.'s categories

\section{Unsustainable strategies}

Post-event coping strategies: eating less, wild food, inferior food

Impact minimising strategy: prefer to improve access to food over access to income Building up stores of food and saleable assets: stocking up

Development of social support networks: marry wealthy family

Creation and maintenance of labour power: have more children

\section{Sustainable strategies}

Preventative strategies: evade seasonal and/or altitudinal concentration of disease vectors; choose locations for housing with less exposure to wind, flood

Diversification of production strategies: planting greater varieties of crops, intercropping , mix-cropping

Diversification of income sources: craft and extractive enterprises, brewing beer

\section{Chambers and Conway's categories}

Stint: reduce current consumption; shift to lower quality foods; draw on energy stored in the body Deplete: draw upon household stores of food; pledge or sell assets

Move: disperse family members, livestock, and assets; and/or migrate

Hoard: accumulate and store food and other assets

Claim: make claims on relatives, neighbours, patrons, the community, NGOs, the government, the international community, variously by calling in debts, appealing to reciprocity and good will, begging, and political action
Protect: preserve and protect the asset base for recovery and reestablishment of the livelihood

Diversify: seek new sources of food-wild foods, gleanings, wild animals, food stored by rats and other animals; diversify work activities and sources of income, especially in offseasons

Source: Adapted from Blaikie et al. (1994, p. 64) and Chambers \& Conway (1992, p. 15)

Table 2: Nature of risks in order of importance according to Jumla respondents based on interview data (risks in bold are reported as most severe)

\begin{tabular}{|c|c|c|}
\hline Trend & Seasonal change & Shock \\
\hline Rise in surface temperature & $\begin{array}{l}\text { Food shortage (hungry } \\
\text { months) }\end{array}$ & Drought and erratic rainfall \\
\hline Drought and erratic rainfall & Strong wind & Strong wind \\
\hline Population growth & Frost & Frost \\
\hline Decline in snow & Road blocks by landslide & Road blocks by landslide \\
\hline $\begin{array}{l}\text { Increased animal and crop } \\
\text { diseases and insects }\end{array}$ & Cold winter & Hail storm \\
\hline Declining soil fertility & & $\begin{array}{l}\text { Bandha or road blockades for } \\
\text { political reasons }\end{array}$ \\
\hline \multirow{5}{*}{$\begin{array}{l}\text { Declining forest area and other } \\
\text { common property resources }\end{array}$} & & Serious illness in the family \\
\hline & & Death in the family \\
\hline & & Armed conflict \\
\hline & & Death of valued animal \\
\hline & & Wild animals destroying crops \\
\hline
\end{tabular}





\section{University Library}

\section{- M M N E R VA A gateway to Melbourne's research publications}

Minerva Access is the Institutional Repository of The University of Melbourne

Author/s:

Gaire, K;Beilin, R;Miller, F

Title:

Withdrawing, resisting, maintaining and adapting: food security and vulnerability in Jumla, Nepal

Date:

2015-12-01

Citation:

Gaire, K., Beilin, R. \& Miller, F. (2015). Withdrawing, resisting, maintaining and adapting: food security and vulnerability in Jumla, Nepal. REGIONAL ENVIRONMENTAL CHANGE, 15 (8), pp.1667-1678. https://doi.org/10.1007/s10113-014-0724-7.

Persistent Link:

http://hdl.handle.net/11343/282531 